Article

\title{
Cytosolic Acidification Is the First Transduction Signal of Lactoferrin-Induced Regulated Cell Death Pathway
}

\author{
María T. Andrés ${ }^{1, *(\mathbb{D})}$, Maikel Acosta-Zaldívar ${ }^{1,2}{ }^{\mathbb{D}}$, Jessica González-Seisdedos ${ }^{1}$ and \\ José F. Fierro ${ }^{1, *(\mathbb{D})}$ \\ 1 Laboratory of Oral Microbiology, University Clinic of Dentistry (CLUO), and Department of Functional \\ Biology (Microbiology), Faculty of Medicine, University of Oviedo, 33006 Oviedo, Asturias, Spain; \\ maikel.acostazaldivar@childrens.harvard.edu (M.A.-Z.); jessiglezsama@gmail.com (J.G.-S.) \\ 2 Present Address: Division of Infectious Diseases, Boston Children's Hospital/Harvard Medical School, \\ Boston, MA 02115, USA \\ * Correspondence: andresmaria@uniovi.es (M.T.A.); jffierro@uniovi.es (J.F.F.); Tel.: +34-985-103643 (M.T.A.); \\ +34-985-102783 (J.F.F.)
}

Received: 30 October 2019; Accepted: 19 November 2019; Published: 20 November 2019

\begin{abstract}
In yeast, we reported the critical role of $\mathrm{K}^{+}$-efflux for the progress of the regulated cell death (RCD) induced by human lactoferrin (hLf), an antimicrobial protein of the innate immune system that blocks Pma1p $\mathrm{H}^{+}$-ATPase. In the present study, the $\mathrm{K}^{+}$channel Tok1p was identified as the $\mathrm{K}^{+}$channel-mediating $\mathrm{K}^{+}$-efflux, as indicated by the protective effect of extracellular $\mathrm{K}^{+}(\geq 30 \mathrm{mM})$, $\mathrm{K}^{+}$-channel blockers, and the greater hLf-resistance of TOK1-disrupted strains. $\mathrm{K}^{+}$-depletion was necessary but not sufficient to induce $\mathrm{RCD}$ as inferred from the effects of valinomycin, $\mathrm{NH}_{4} \mathrm{Cl}$ or nigericin which released a percentage of $\mathrm{K}^{+}$similar to that released by lactoferrin without affecting cell viability. Cytosolic $\mathrm{pH}$ of hLf-treated cells decreased transiently ( $\sim 0.3 \mathrm{pH}$ units) and its inhibition prevented the RCD process, indicating that cytosolic acidification was a necessary and sufficient triggering signal. The blocking effect of lactoferrin on Pmalp $\mathrm{H}^{+}$-ATPase caused a transitory decrease of cytosolic $\mathrm{pH}$, and the subsequent membrane depolarization activated the voltage-gated $\mathrm{K}^{+}$channel, Tok1p, allowing an electrogenic $\mathrm{K}^{+}$-efflux. These ionic events, cytosolic accumulation of $\mathrm{H}^{+}$followed by $\mathrm{K}^{+}$-efflux, constituted the initiating signals of this mitochondria-mediated cell death. These findings suggest, for the first time, the existence of an ionic signaling pathway in RCD.
\end{abstract}

Keywords: lactoferrin; Candida albicans; potassium efflux; cytosolic acidification; regulated cell death; apoptosis-like; cell signaling pathway

\section{Introduction}

Human lactoferrin (hLf) is an antimicrobial protein of the innate immune system that induces a regulated cell death (RCD) in Candida albicans, a commensal yeast that is also an important human opportunistic pathogen [1-3]. In yeast, hLf-induced RCD shares many of the apoptotic cell death characteristics observed in metazoan cells, and for this reason was previously identified as an apoptosis-like process [2,4]. We previously demonstrated that potassium efflux ( $\mathrm{K}^{+}$-efflux) is a critical step for the progress of RCD induced by lactoferrin, as it is in higher eukaryotic cells [2]. Furthermore, we identified Pma1p $\mathrm{H}^{+}$-ATPase (type $\mathrm{P}_{3 \mathrm{~A}}$ ) as the molecular target of lactoferrin on the plasma membrane, the first reported RCD receptor in fungi [4]. Because the cytosolic accumulation of $\mathrm{K}^{+}$ depends on the electrochemical gradient generated by the plasma membrane Pma1p $\mathrm{H}^{+}$-ATPase, we hypothesized that the blocking effect of lactoferrin on this ATPase caused a sequential perturbation of ionic homeostasis [5-7]. This ionic perturbation, which mainly included $\mathrm{H}^{+}$and $\mathrm{K}^{+}$ions, occurred at 
the cytoplasmic and mitochondrial level leading to regulated cell death. In this process, we reported the central role of mitochondria, specifically ATP synthase, for the subsequent progress of RCD induced by lactoferrin $[4,8]$.

Potassium efflux, mediated by a wide variety of $\mathrm{K}^{+}$channels, has been well documented in many apoptotic model systems using multicellular and unicellular eukaryotes but the underlying mechanism(s) remain largely elusive [9-22]. Moreover, it is unknown why $\mathrm{K}^{+}$-depletion is critical for progress on the apoptotic pathway. Low intracellular potassium could favor cell death by initiating various pro-apoptotic processes such as activation of intracellular enzymes, and hyperpolarization of the plasma membrane and osmotic lysis of vacuoles $[12,17,23]$. These proposals imply that $\mathrm{K}^{+}$-efflux is a sufficient condition to trigger the RCD process, an idea that is apparently supported by different observations made both in higher eukaryotic cells and in yeasts, in which blocking of the outward $\mathrm{K}^{+}$ channels prevents regulated cell death $[2,14,24,25]$.

In parallel, cytosolic acidification is also an early event observed in apoptosis of eukaryotic cells, including yeasts [26-28]. Rapid and transient changes of cytosolic $\mathrm{pH}$ may act as intracellular signals of important cellular functions [29-31]. However, the role of cytosolic acidification in regulated cell death has not been explored. It is thought that the ionic imbalance during the RCD process is a consequence of the structural and functional alterations experienced by the dying cell rather than early signals of a putative intracellular signaling pathway [14].

The above arguments raise the question of whether $\mathrm{K}^{+}$- and $\mathrm{H}^{+}$-flux represent intermediate signals required for the induction of RCD and whether they are causally linked. The aim of this study was to identify the intracellular signal responsible for RCD activation in response to the blocking effect of human lactoferrin on Pma1p $\mathrm{H}^{+}$-ATPase. For that purpose, we used a simplified experimental system, which included: (i) a unicellular eukaryote (C. albicans), (ii) a target-specific inducer of regulated cell death process (lactoferrin), and iii) a salt-free buffer. Using these minimal elements and restricted test conditions, current work focused on elucidating the first ionic cytosolic events related to RCD and was undertaken with the following objectives: (a) to evaluate whether inhibition of lactoferrin activity by extracellular $\mathrm{K}^{+}$would result from either cation- and/or osmotic-induced changes in the microorganism or by inhibition of the protein-target interaction; (b) to identify the $\mathrm{K}^{+}$-channel putatively involved in the RCD process induced by lactoferrin; (c) to determine whether cellular $\mathrm{K}^{+}$-efflux is a sufficient signal to initiate RCD or merely a consequence of other previous events; and in this latter case, (d) to identify possible upstream event/s of the RCD pathway promoting flow of $\mathrm{K}^{+}$out of the cell ( $\mathrm{K}^{+}$-efflux).

The understanding of the early signaling function of cytosolic ions in the RCD sequence and its possible extrapolation to higher eukaryotic cells may lead to therapeutic applications in the future and new concepts.

\section{Results}

\subsection{Effect of Extracellular Factors on the RCD Induced by Lactoferrin}

In previous reports, we showed that the candidacidal effect caused by lactoferrin is a type of regulated cell death (i.e., apoptosis-like process) that can be prevented by the presence of extracellular $\mathrm{K}^{+}[2,32]$. Lactoferrin-treated cells suspended in Tris buffer or potassium phosphate buffer $(10 \mathrm{mM}$ $\mathrm{K}_{2} \mathrm{HPO}_{4}-\mathrm{KH}_{2} \mathrm{PO}_{4}, \mathrm{pH} 7.4$ ), containing different concentrations of $\mathrm{KCl}$, were fully protected from the lactoferrin killing activity at $\geq 30 \mathrm{mM}$ potassium (Figure 1A). The comparison of the inhibition patterns obtained in each of these different buffers showed a similar dependence of the $\mathrm{K}^{+}$concentration and indicated that only extracellular $\mathrm{K}^{+}$was involved in the inhibition of the candidacidal activity of lactoferrin.

It is known that the properties of the microbial cell wall and other experimental factors can influence the susceptibility to many cationic antimicrobial peptides [33]. Therefore, we evaluated whether cellular protection mediated by extracellular $\mathrm{K}^{+}$was a consequence of either the ionic strength or the osmotic conditions used. Figure $1 \mathrm{~B}$ shows the data of the killing assays performed in $\mathrm{KCl}$ or 
$\mathrm{LiCl}$ solutions adjusted to different ionic strengths $(I)$. In the presence of $\mathrm{K}^{+}$, the candidacidal activity of lactoferrin was inhibited by $93 \% \pm 5 \%$ and $100 \%$ by $I$ values of 0.02 and 0.03 , respectively. In the presence of $\mathrm{Li}^{+}$, used to obtain $I$ values similar to those of $\mathrm{KCl}$ solutions, only partial protection ( $\leq 36 \%$ cell survival) was observed in hLf-treated cells to $I \geq 0.01$, suggesting an unknown alternative mechanism. However, the cell viability patterns obtained in the presence of these monovalent cations were clearly different, showing that the candidacidal activity of lactoferrin was abrogated by $I \geq 0.03$ in the presence of $\mathrm{K}^{+}$.

To determine whether the protective effect of extracellular $\mathrm{K}^{+}$was due to extracellular osmotic conditions, we tested lactoferrin activity under equivalent osmolarity values $\mathrm{KCl}$ and sorbitol, a non-ionic osmotic stabilizer. Although partial inhibition was observed at lower osmolarity values of sorbitol ( $\leq 80 \mathrm{mOsm}$ ), higher osmolarity values, which were equivalent to $\geq 20 \mathrm{mM} \mathrm{KCl}$, were not inhibitory with respect to the control assays performed in Tris buffer alone. For example, $300 \mathrm{mOsm}$ sorbitol, comparable in osmotic strength with $150 \mathrm{mM} \mathrm{KCl}$ or $140 \mathrm{mM} \mathrm{NaCl}$, was unable to inhibit the regulated cell death induced by lactoferrin (Figure 1C). Therefore, the activity of lactoferrin was not significantly modified by different osmotic conditions associated with extracellular $\mathrm{K}^{+}$concentration over a wide range of concentrations.

Lactoferrin blocks Pma1p $\mathrm{H}^{+}$-ATPase by preventing the extrusion of cytosolic protons out of the cell membrane, an effect that can easily be observed by a glucose-induced proton extrusion test [4]. In glucose-induced extracellular acidification assays, the blocking effect of hLf on Pma1p $\mathrm{H}^{+}$-ATPase remained unchanged in the presence of $\mathrm{K}^{+}$concentrations $(30$ and $50 \mathrm{mM}$ ) that inhibit the candidacidal activity of lactoferrin (Figure 1D).

These results suggest that the inhibitory effect of extracellular $\mathrm{K}^{+}(\geq 30 \mathrm{mM})$ on lactoferrin-induced regulated cell death was not due to the experimental conditions used, such as low ionic strength and osmolarity, nor to other factors that could prevent the interaction between Pma1p H $\mathrm{H}^{+}$-ATPase and lactoferrin.

A

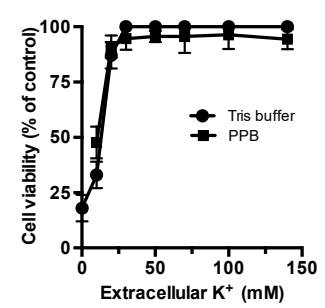

B

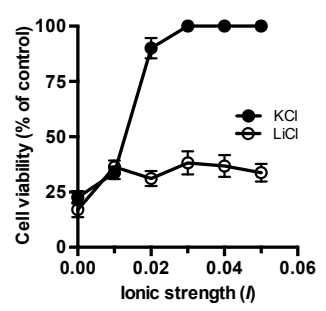

C

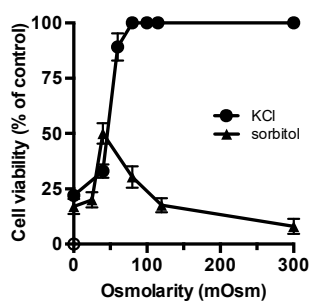

D

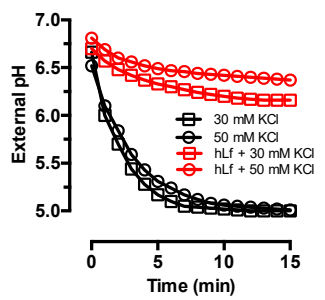

Figure 1. Influence of extracellular factors on lactoferrin-induced regulated cell death. C. albicans cells $\left(10^{5}\right.$ cells $/ \mathrm{mL}$ ) were incubated with $5 \mu \mathrm{M}$ lactoferrin (hLf) for $90 \mathrm{~min}$ at $37^{\circ} \mathrm{C}$ in the presence of (A) different extracellular $\mathrm{K}^{+}$concentrations in Tris buffer (circles) or potassium phosphate buffer (PPB, squares); (B) different ionic strength calculated in the presence of $\mathrm{KCl}$ (solid circles) and $\mathrm{LiCl}$ (open circles) solutions; or (C) equivalent osmolarity values of $\mathrm{KCl}$ (circles) or sorbitol (triangles) solutions. The cell viability was determined by a plate-count method. (D) Effect of extracellular $\mathrm{K}^{+}$on the interaction of lactoferrin with the $\mathrm{H}^{+}$-ATPase. The $\mathrm{H}^{+}$-extrusion mediated by the plasma membrane Pma1p $\mathrm{H}^{+}$-ATPase of C. albicans cells suspended in $30 \mathrm{mM} \mathrm{KCl}$ (squares) or $50 \mathrm{mM} \mathrm{KCl}$ (circles) was determined in the presence (red lines) or in the absence (black lines, control) of lactoferrin by monitoring glucose-induced acidification of the external medium. The results are the means \pm SD from duplicates of at least three independent experiments. In Figure 1D, only the mean data $(n=3)$ are shown, and the bars representing standard errors (coefficient of variation of $<10 \%$ ) are omitted for clarity.

\subsection{Identification of $\mathrm{K}^{+}$Transporters in the $R C D$ Process}

The efflux of potassium is a critical event for the RCD progress induced by lactoferrin, and we have previously showed that tetraethylammonium (TEA) and 4-aminopyridine (4-AP), blockers of voltage-gated $\mathrm{K}^{+}$-channels, prevented the candidacidal activity of this cell membrane depolarizing 
protein [2,34]. Figure 2A shows that C. albicans cells pre-incubated in Tris buffer containing $10 \mathrm{mM}$ TEA exhibited a high lactoferrin resistance compared to cells treated only with lactoferrin $(92 \% \pm 6 \%$ versus $19 \% \pm 4 \%$ cell survival, respectively). Similarly, cells pre-incubated in the presence of $\mathrm{Ba}^{2+}$ $(10 \mu \mathrm{M} \mathrm{BaCl} 2)$, a selective inhibitor of the outward $\mathrm{K}^{+}$-channel Tok1p of $C$. albicans, were significantly more resistant to lactoferrin $(71 \% \pm 8 \%$ versus $19 \% \pm 4 \%$ cell survival, respectively) [35]. After $90 \mathrm{~min}$, potassium released from lactoferrin-treated cells pre-incubated with either TEA or $\mathrm{BaCl}_{2}$ was substantially lower than what $\mathrm{K}^{+}$released from cells exposed only to lactoferrin or nystatin (Figure 2B). The latter is a partially selective pore-forming agent in the plasma membrane of fungi that mainly releases ions and small molecules from cytosol.

The preventive effect of TEA and $\mathrm{Ba}^{2+}$ supported the participation of Tok1p channels for the progress of the cell death pathway induced by lactoferrin. To assess this possibility, the susceptibility to lactoferrin of TOK1-disrupted strains C. albicans DBT2 (TOK1/tok1) and DBT3 (tok1/tok1) was compared with that of their parental strain C. albicans CAI4 (TOK1/TOK1), the strain expressing both wild-type alleles of TOK1 functional. Figure 2C shows that the strains DBT2 and DBT3 were significantly more resistant than the strain CAI4 (95\% $\pm 4 \%$ and $98 \% \pm 2 \%$ versus $57 \% \pm 8 \%$ cell survival, respectively) to $1.25 \mu \mathrm{M}$ lactoferrin. The involvement of the Tok1p channels in the cell death was also reflected in the different susceptibility to lactoferrin of both modified strains (Figure 2C). The strain DBT3, without functional TOK1 alleles, was substantially more resistant with respect to the DBT2 strain with one functional TOK1 allele (35\% $\pm 9 \%$ versus $69 \% \pm 7 \%$ cell survival, respectively). Thus, two TOK1 disruptions doubled the viability increment produced by a single disruption when these TOK1-disrupted strains were exposed to $2.5 \mu \mathrm{M}$ lactoferrin (Figure 2C).

An examination of all the above data indicate that, under our experimental conditions, the $\mathrm{K}^{+}$-efflux in the presence of lactoferrin, a protein that causes plasma membrane depolarization, was mediated by the Tok1p channel, a voltage-gated $\mathrm{K}^{+}$channel that is activated only by plasma membrane depolarization $[32,36,37]$.

A

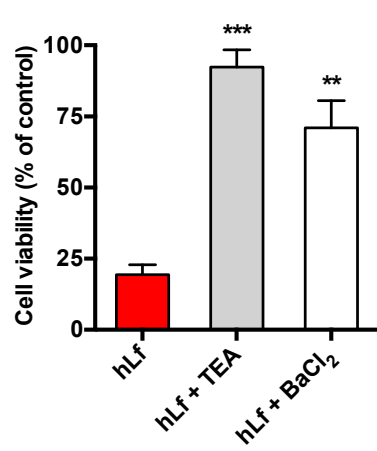

B

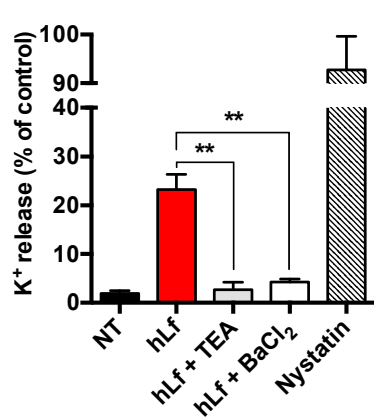

C

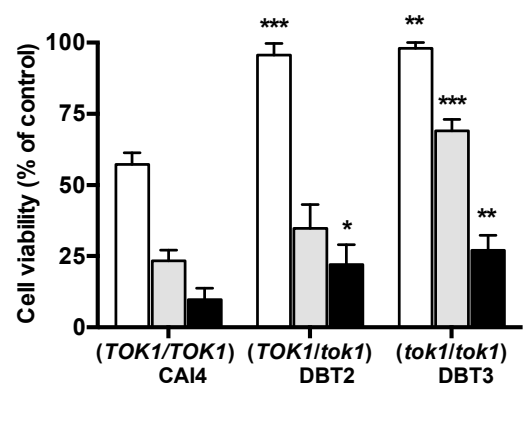

Figure 2. Identification of $\mathrm{K}^{+}$-channel involved in the lactoferrin-induced RCD process. (A) Viability of yeast cells $\left(10^{5}\right.$ cells $\left./ \mathrm{mL}\right)$ suspended in Tris buffer and treated with $5 \mu \mathrm{M}$ lactoferrin ( $\mathrm{hLf}$, red column) or pre-incubated for $15 \mathrm{~min}$ at $37^{\circ} \mathrm{C}$ with the $\mathrm{K}^{+}$-channel inhibitors tetraethylammonium (10 mM TEA; gray column) or $\mathrm{Ba}^{2+}\left(10 \mu \mathrm{M} \mathrm{BaCl}_{2}\right.$; white column) before the addition of $5 \mu \mathrm{MhLf}$. (B) Potassium efflux measured from non-treated cells (NT) assayed under the above conditions (black column; negative control), treated with hLf alone (red column) or pre-incubated with $10 \mathrm{mM}$ TEA (gray column) or $10 \mu \mathrm{M} \mathrm{BaCl}_{2}$ (white column) before the addition of lactoferrin. Nystatin $(100 \mu \mathrm{g} / \mathrm{mL}$ ) was used as a positive control of $\mathrm{K}^{+}$released by permeabilized cells (dashed column). (C) Antifungal activity of three concentrations of hLf on C. albicans TOK1-disrupted strains. The strains $\left(10^{5}\right.$ cells $\left./ \mathrm{mL}\right)$ were incubated for $90 \mathrm{~min}$ at $37^{\circ} \mathrm{C}$ with $1.25 \mu \mathrm{M}$ (white column), $2.5 \mu \mathrm{M}$ (gray column), or $5 \mu \mathrm{M}$ (black column) of lactoferrin. All the percentages of viability and $\mathrm{K}^{+}$released correspond to cells suspended in Tris buffer and incubated with hLf for $90 \mathrm{~min}$ at $37^{\circ} \mathrm{C}$. The cell viability was determined by a plate-count method. The results are the means $\pm \mathrm{SD}$ from duplicates of at least three independent experiments. Statistical significance was assessed by Student's $t$ test. ${ }^{*} p<0.05 ;{ }^{* *} p<0.01 ;{ }^{* * *} p<0.001$. 


\subsection{Effect of Cellular $\mathrm{K}^{+}$Depletion on RCD Triggering}

Lactoferrin induces a RCD in yeast which is accompanied of $\mathrm{K}^{+}$-efflux during the first $20 \mathrm{~min}$ of treatment [34]. To determine if cellular $\mathrm{K}^{+}$depletion is a sufficient signal for activation of the regulated cell death pathway, C. albicans cells were exposed to different chemical agents that decrease the intracellular $\mathrm{K}^{+}$concentration by different mechanisms of action.

\subsubsection{Effect of Valinomycin-Mediated $\mathrm{K}^{+}$Release on Cell Viability}

Cells were incubated $\left(90 \mathrm{~min}\right.$ at $\left.37^{\circ} \mathrm{C}\right)$ with valinomycin $(50 \mu \mathrm{g} / \mathrm{mL})$, a K ${ }^{+}$-selective ionophore, or $5 \mu \mathrm{M}$ lactoferrin (positive control), and cell viability was determined after 24,48 and $72 \mathrm{~h}$ by a plate-count method. After incubating the plates for $24 \mathrm{~h}$, the viability of the cells treated with valinomycin or lactoferrin significantly decreased $(5 \% \pm 2 \%$ and $15 \% \pm 4 \%$ cell survival, respectively), a result compatible with a candidacidal effect for both agents (Figure 3A). However, the same plates containing the valinomycin-treated cells showed late growth, forming small colonies $(83 \% \pm 7 \%$ cell survival) after a 48-h incubation. These colonies, delayed in their growth with respect to the control (cells not treated with valinomycin), reached a complete development at $72 \mathrm{~h}$. Conversely, no recovery of viability of lactoferrin-treated cells was observed even after $72 \mathrm{~h}$ of incubation $(16 \% \pm 2 \%$ cell survival), a congruent result for a protein that induces a RCD process.

We interpreted that cells incubated with valinomycin alone, suspended in $\mathrm{K}^{+}$-free media (Tris buffer), were depleted of $\mathrm{K}^{+}$ions to an intracellular level non compatible with cell viability. These apparently non-viable but vital cells restored their intracellular $\mathrm{K}^{+}$concentration after they were spread onto SDA plates, where $\mathrm{K}^{+}$uptake was restored and the concentration of valinomycin present in the inoculum was diluted by diffusion in the solid medium, thus recovering their cell viability but showing a delay in the formation of colonies with respect to the control.

To investigate whether the differences of antifungal activity of valinomycin and lactoferrin could be explained by possible differences in their ability to deplete intracellular $\mathrm{K}^{+}$ions, the $\mathrm{K}^{+}$released in the presence of each of these compounds was compared with respect to the total cellular $\mathrm{K}^{+}$content $(100 \%)$. Interestingly, valinomycin- and lactoferrin-treated cells released a similar percentage of $\mathrm{K}^{+}(25 \% \pm 4 \%$ and $23 \% \pm 3 \%$, respectively) with a similar kinetic release pattern (Figure 3B). A progressive potassium release was detected during the first $20 \mathrm{~min}$, further remaining without changes. The similarity in the percentage and releasing- $\mathrm{K}^{+}$pattern of valinomycin- and lactoferrin-treated cells, compared with the total cellular $\mathrm{K}^{+}$content and the percentage of $\mathrm{K}^{+}$released by nystatin-treated cells, suggested that $\mathrm{K}^{+}$-efflux was electrogenic.

\subsubsection{Effect of $\mathrm{NH}_{4} \mathrm{Cl}$-Mediated $\mathrm{K}^{+}$Extrusion on Cell Viability}

It was previously reported that yeast cells at $\mathrm{pH} 8.0$ only extrude cellular $\mathrm{K}^{+}(>50 \%)$ in the presence of ammonium chloride [38]. The loss of intracellular $\mathrm{K}^{+}$was described as the consequence of the rapid cytosolic alkalinization induced by extracellular $\mathrm{NH}_{4}{ }^{+}[38,39]$. This cationic molecule is then converted to electroneutral $\mathrm{NH}_{3}$ at alkaline $\mathrm{pH}$ and diffuses into cells where it binds to free cytosolic protons. Subsequently, the cytosolic alkalinization is compensated by a homeostatic response involving the exchange of intracellular $\mathrm{K}^{+}$by $\mathrm{H}^{+}$, to restore the initial cytosolic $\mathrm{pH}$ values [38].

In our assays, the viability of cells treated with $10 \mathrm{mM} \mathrm{NH}_{4} \mathrm{Cl}$ was not substantially modified with respect to untreated cells (Figure 3C). However, the release of $\mathrm{K}^{+}$from $\mathrm{NH}_{4} \mathrm{Cl}$-treated cells was approximately $54 \%$ of total intracellular $\mathrm{K}^{+}$after $90 \mathrm{~min}$ (Figure 3D). Then, the release of $\mathrm{K}^{+}$in $\mathrm{NH}_{4} \mathrm{Cl}$-treated cells was twice that observed in lactoferrin or valinomycin-treated cells without this greater loss of $\mathrm{K}^{+}$substantially affecting their viability.

\subsubsection{Effect of Nigericin-Mediated $\mathrm{K}^{+} / \mathrm{H}^{+}$Exchange on Cell Viability}

The lipophilic ionophore nigericin mediates electroneutral antiport of $\mathrm{K}^{+}$and $\mathrm{H}^{+}$across biological membranes, thus mimicking the intracellular ionic context caused by lactoferrin. Nigericin-induced 
regulated cell death of $S$. cerevisiae cells with a declining intracellular $\mathrm{pH}$ was previously reported [40]. In a similar way, the viability of nigericin-treated C. albicans cells was estimated as $53 \%$, a significant loss of viability with respect to untreated cells.

\subsubsection{Effect of Piericidin A on the Lactoferrin Induced $\mathrm{K}^{+}$-efflux}

The lactoferrin-treated cells were pre-incubated with $16 \mu \mathrm{M}$ piericidin $\mathrm{A}$ for $15 \mathrm{~min}$ at $37^{\circ} \mathrm{C}$ to inhibit the complex I of the respiratory chain of $C$. albicans cells. Measurement of the $\mathrm{K}^{+}$released from cells pre-incubated with piericidin A showed a similar percentage of $\mathrm{K}^{+}$released with respect to that measured from cells treated with lactoferrin alone ( $27 \%$ versus $24 \%$ of $\mathrm{K}^{+}$released, respectively). However, piericidin A is an effective protector of lactoferrin-induced RCD, as we previously reported [4], indicating again that $\mathrm{K}^{+}$-efflux alone is not sufficient to initiate RCD and that this critical step could be a consequence of a previous signaling event related to proton balance.

A

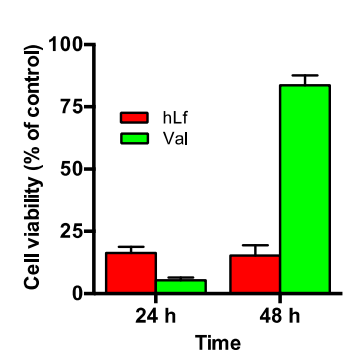

B

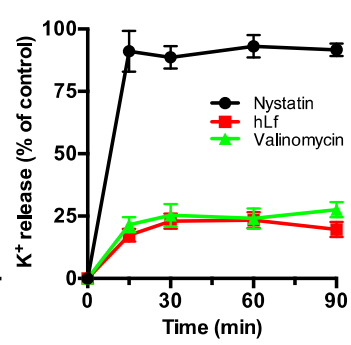

C

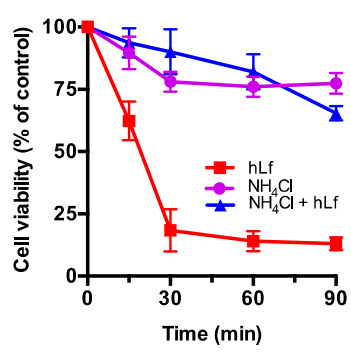

D

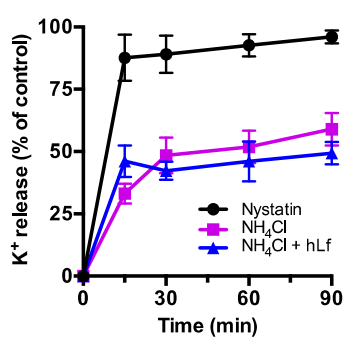

Figure 3. Effect of different $\mathrm{K}^{+}$-depletion inducers on cell viability. (A) Antifungal activity of lactoferrin and valinomycin. The cells $\left(10^{5}\right.$ cells/mL) were incubated in Tris buffer for $90 \mathrm{~min}$ at $37^{\circ} \mathrm{C}$ with $5 \mu \mathrm{M}$ lactoferrin (hLf, red column) or $50 \mu \mathrm{g} / \mathrm{mL}$ valinomycin (Val; green column) and cell viability was calculated at $24 \mathrm{~h}$ and $48 \mathrm{~h}$. (B) Time-course of $\mathrm{K}^{+}$release induced by lactoferrin and valinomycin. The $\mathrm{K}^{+}$ released was measured at different times after the addition of $20 \mu \mathrm{M}$ lactoferrin (red line), $50 \mu \mathrm{g} / \mathrm{mL}$ valinomycin (green line), or $100 \mu \mathrm{g} / \mathrm{mL}$ nystatin (black line, positive control) to cell suspensions $\left(10^{7}\right.$ cells $/ \mathrm{mL}$ ). (C) Effect of $\mathrm{NH}_{4} \mathrm{Cl}$ on viability of lactoferrin-treated cells. The time-kill curve of cells $\left(10^{5}\right.$ cells $\left./ \mathrm{mL}\right)$, pre-incubated in the presence of $10 \mathrm{mM} \mathrm{NH}_{4} \mathrm{Cl}$ and treated with (blue line) or without $5 \mu \mathrm{M}$ hLf (purple line) to determine cell viability. Lactoferrin-treated cells in the absence of $\mathrm{NH}_{4} \mathrm{Cl}$ (red line) were used as control. (D) Time-course of $\mathrm{K}^{+}$-release in the presence of $\mathrm{NH}_{4} \mathrm{Cl}$. Cell suspensions were treated with (blue line) or without $20 \mu \mathrm{M} \mathrm{hLf}$ (purple line) in the presence of $10 \mathrm{mM} \mathrm{NH}_{4} \mathrm{Cl}$. The $\mathrm{K}^{+}$release was determined at different times of the incubation period performed at $37^{\circ} \mathrm{C}$. Nystatin $(100 \mu \mathrm{g} / \mathrm{mL})$ was used as positive control in the measurements of released $\mathrm{K}^{+}$. Each value shown is the mean \pm SD from duplicates of at least three independent experiments.

\subsection{Evaluation of the Role of Cytosolic $\mathrm{pH}$ in Regulated Cell Death Triggering}

Since lactoferrin inhibits Pma1p $\mathrm{H}^{+}$-ATPase, an early accumulation of protons in the cytosol of metabolically active cells is expected under our experimental conditions. This raises the question of whether changes in intracellular $\mathrm{pH}$ could represent, in our case, the first intracellular signal of a hypothetical signaling pathway of cell death.

Monitoring intracellular $\mathrm{pH}$ by applying the ratiometric pHluorin method in the C. albicans JKC1562 strain showed a rapid drop in cytosolic $\mathrm{pH}$ estimated in approximately $0.3 \mathrm{pH}$ units (6.33 to 6.02) after approximately $1 \mathrm{~min}$ of lactoferrin addition. This acidic $\mathrm{pH}$ shift was followed by a slow but progressive cytosolic alkalinization that reached the initial $\mathrm{pH}$ value $(\mathrm{pH}$ 6.33) approximately $6 \mathrm{~min}$ later (Figure 4). In a similar way, diethylstilbestrol (DES), a known Pma1p $\mathrm{H}^{+}$-ATPase specific blocking agent, elicited a rapid but weaker response compared with the transient cytosolic acidification induced by lactoferrin (Figure 4). 
A

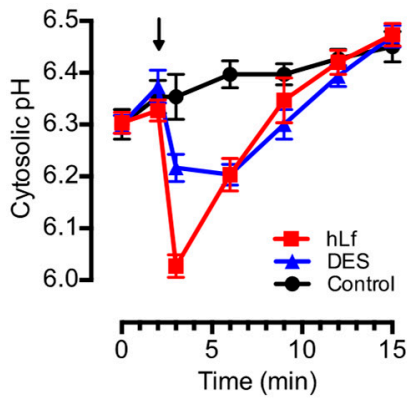

C

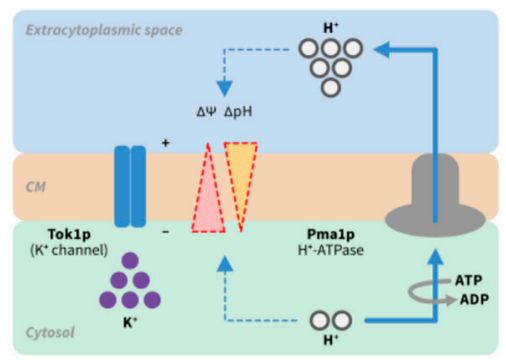

B

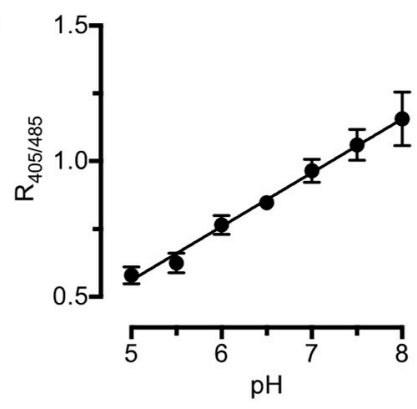

D

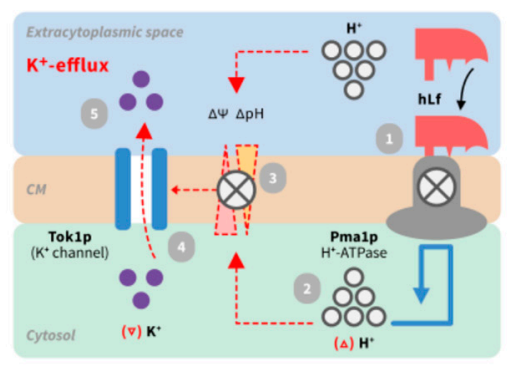

Figure 4. Effect of lactoferrin on cytosolic $\mathrm{pH}$. (A) Transient cytosolic acidification induced by lactoferrin. Cytosolic $\mathrm{pH}$ of $\mathrm{C}$. albicans-adapted pHluorin cells (black line, control), exposed to $5 \mu \mathrm{M}$ lactoferrin (red line) or $25 \mu \mathrm{M}$ diethylstilbestrol (DES, blue line), was determined at different times. These inhibitors of fungal Pma1 $\mathrm{H}^{+}$-ATPase were added to the cell suspensions at the indicated time (arrow). Cytosolic $\mathrm{pH}$ values were derived from fluorescence intensity measurements at different times over $15 \mathrm{~min}$ and calculated according to the calibration curve. (B) Calibration curve showing measured ratio of fluorescence intensity at $405 \mathrm{~nm}$ to intensity at $485 \mathrm{~nm}$ versus $\mathrm{pH}$ of pHluorin-expressing permeabilized cells equilibrated in buffers of increasing $\mathrm{pH}$. Data are shown as means \pm SD from duplicates of at least three independent experiments. (C) The normal activity of Pma1p H ${ }^{+}$-ATPase of cytoplasmic membrane $(\mathrm{CM})$ generates a proton gradient $(\Delta \mathrm{pH})$ and an electrical $(\Delta \Psi)$ gradient (negative inside) indicated by dashed lines. Cytosolic $\mathrm{K}^{+}$is retained by the negative electrical charge. (D) The figure shows the sequence of linked events induced by lactoferrin (i.e., cytosolic acidification and $\mathrm{K}^{+}$-efflux). The blocking effect of lactoferrin on Pma1p H $\mathrm{H}^{+}$-ATPase (1) causes a transient accumulation of protons in cytosol, detected as cytosolic acidic $\mathrm{pH}$ shift (2), and the subsequent loss of electrochemical gradient (3). As a consequence, the voltage-dependent channel Tok1p opens upon plasma membrane depolarization (4) allowing $\mathrm{K}^{+}$-efflux (5).

\section{Discussion}

Accumulated evidence indicates that reduced concentrations of intracellular $\mathrm{K}^{+}$provide a permissive cytosolic environment for apoptosis and that elevation of extracellular $\mathrm{K}^{+}$prevents this type of regulated cellular death (RCD) in higher eukaryotic cells and yeast $[2,12,14]$. Similarly, $\mathrm{K}^{+}$-efflux is a critical stage for the progress of the RCD process induced in yeast by lactoferrin and was also observed with different inducers of RCD in fungi such as acetic acid, chlorogenic acid, glucose, Penicillium chrysogenum antifungal protein, and sorbic acid indicating also its importance in the RCD process of lower eukaryotic cells $[17,21,41-43]$. However, an explanation of the intracellular mechanism(s) by which cellular $\mathrm{K}^{+}$-efflux occurs and why this event is critical for the progress of the RCD cascade remains to be elucidated [13-15].

Previous work demonstrated that lactoferrin targets Pma1p $\mathrm{H}^{+}$-ATPase, inducing a regulated cell death, mediated by $\mathrm{K}^{+}$-efflux, that was inhibited by extracellular $\mathrm{K}^{+}$by unknown mechanism/s $[2,32]$. Since lactoferrin is a cationic glycoprotein $(\mathrm{pI} \sim 8.7)$ at assayed $\mathrm{pH}(\mathrm{pH} 7.4)$, the loss of activity could be due to a competitive effect of $\mathrm{K}^{+}$cations for the lactoferrin-binding sites shielding them from this antimicrobial factor. However, our data from time-kill experiments show that the preventive effect of extracellular $\mathrm{K}^{+}(\geq 30 \mathrm{mM})$ was not related to decreased cell binding of lactoferrin nor other cellular 
changes associated to the experimental conditions. Therefore, we reasoned that the flow of $\mathrm{K}^{+}$was an ionic homeostatic response to the blocking effect of lactoferrin on Pma1p $\mathrm{H}^{+}$-ATPase. In this respect, we assumed that the reported plasma membrane depolarization of hLf-treated cells was partially due to the dissipation of the proton gradient $(\Delta \mathrm{pH})$ caused by the cytosolic accumulation of $\mathrm{H}^{+}$, after Pma1p $\mathrm{H}^{+}$-ATPase inhibition. In turn, the electrical negative force that retained intracellular $\mathrm{K}^{+}$was eliminated and positively charged $\mathrm{K}^{+}$ions passively flowed out of the cell through specific outward $\mathrm{K}^{+}$channels, yielding a measurable $\mathrm{K}^{+}$-efflux $[4,32]$. To further evaluate this idea, we first performed the identification of the putative $\mathrm{K}^{+}$-channels related with this early apoptotic event.

In yeast, the cation transporters Nha1, Ena1-4, and Tok1p are the only known channels involved in the $\mathrm{K}^{+}$-efflux $[7,44]$. The activity of Nha1, a Na ${ }^{+}\left(\mathrm{K}^{+}\right) / \mathrm{H}^{+}$antiporter, is dependent on the proton gradient generated by the Pma1p $\mathrm{H}^{+}$-ATPase, blocked by lactoferrin in our assays. Moreover, the ability of Ena1-4, a Na ${ }^{+}\left(\mathrm{K}^{+}\right)$transport ATPase, to extrude $\mathrm{K}^{+}$has not been reported for Candida genus. Consequently, the involvement of Nha1 and Ena 1-4 in the $\mathrm{K}^{+}$-efflux induced by lactoferrin was excluded. The only outward-rectifying $\mathrm{K}^{+}$-channel present in the plasma membrane of yeast cells is Tok1p, a voltage-dependent outward rectifier channel that releases $\mathrm{K}^{+}$exclusively when activated by membrane depolarization [36,45]. The Tok1p channel is blocked by TEA ${ }^{+}$and $\mathrm{Ba}^{2+}$ cations [45]. C. albicans cells pre-incubated with TEA or $\mathrm{BaCl}_{2}$ were significantly more resistant to lactoferrin compared to the non-treated cells, and this was correlated with a clear decrement of $\mathrm{K}^{+}$efflux. In a similar way, C. albicans TOK1-disrupted strains (TOK1/tok1, and tok1/tok1) exhibit an increased resistance to low concentrations of lactoferrin. These results indicated that, under our experimental conditions, the $\mathrm{K}^{+}$-efflux was mediated by the Tok1p channel. To our knowledge, this is the first report identifying a $\mathrm{K}^{+}$-channel involved in the regulated cell death of fungi.

It is noteworthy that the analysis of the data of the $\mathrm{K}^{+}$-efflux of cells treated with lactoferrin showed a kinetic pattern, similar to that obtained using valinomycin alone, compatible with an electrogenic flow through the plasma membrane. It seems that $\mathrm{K}^{+}$ions left the cell through Tok1p channels driven by its concentration gradient but generating behind an unbalanced electric charge (negative inside), which prevented a greater $\mathrm{K}^{+}$-efflux. This could explain two of our previous results obtained using hLf-treated cells $[4,34]$ : (a) the relatively small percentage of $\mathrm{K}^{+}$released from the cells (approximately $25 \%$ of total $\mathrm{K}^{+}$cellular content), and (b) the protective effect of external $\mathrm{K}^{+}$on the candidacidal activity of lactoferrin. In the latter case, the complete dissipation of $\mathrm{K}^{+}$-gradient occurred when extracellular $\mathrm{K}^{+}$was $\geq 30 \mathrm{mM}$, avoiding the $\mathrm{K}^{+}$-efflux and the subsequent cell death.

The above results suggest that preservation of intracellular $\mathrm{K}^{+}$, due to Tok1p blocking or to the loss of $\mathrm{K}^{+}$gradient, prevented the regulated cell death. In this case, the question arises whether only $\mathrm{K}^{+}$-efflux could be sufficient to activate RCD.

If the loss of intracellular $\mathrm{K}^{+}$is a necessary and sufficient signal for a cell to undergo regulated cell death, then chemical induction of $\mathrm{K}^{+}$depletion should trigger a similar RCD process. To test this suggestion, C. albicans cells were exposed to three chemical agents (i.e., valinomycin, $\mathrm{NH}_{4} \mathrm{Cl}$, nigericin) which promote a clear decrease in intracellular $\mathrm{K}^{+}$concentration by different mechanisms. The neutral ionophore valinomycin forms plasma membrane permeant complexes with intracellular $\mathrm{K}^{+}$(valinomycin- $\mathrm{K}^{+}$) which exhibit a positive charge. Consequently, an outward movement of valinomycin- $\mathrm{K}^{+}$complexes across the plasma membrane is generated. In our experimental conditions, the transmembrane flux of valinomycin- $\mathrm{K}^{+}$complexes was only dependent on the $\mathrm{K}^{+}$ gradient, but limited by the electrical gradient (negative inside) generated by the outward flux of valinomycin- $\mathrm{K}^{+}$. Supporting this scenario, the determination of extracellular $\mathrm{K}^{+}$from valinomycinand hLf-treated cell suspensions showed similarity in both efflux kinetics and percentage of $\mathrm{K}^{+}$released (approximately $25 \%$ ), suggesting that $\mathrm{K}^{+}$-efflux induced by lactoferrin was electrogenic. Surprisingly, valinomycin-treated cells were unable to undergo a regulated cell death, and only a delayed growth of the colonies was observed. Although the valinomycin effect on other cell organelles was not evaluated, the above data are consistent with our previously reported observations and hypothesis, suggesting 
that the observed $\mathrm{K}^{+}$-efflux in hLf-treated cells is a necessary step for the progress of the RCD pathway but it is not the essential activator of the RCD process [4,32].

According to these results and in order to clarify the role of $\mathrm{K}^{+}$depletion in the activation of the $\mathrm{RCD}$ sequence, the cells were also exposed to ammonium chloride $\left(\mathrm{NH}_{4} \mathrm{Cl}\right)$, a chemical compound that promotes a high $\mathrm{K}^{+}$-efflux concomitantly with a cytosolic alkalization [38]. In the presence of $\mathrm{NH}_{4} \mathrm{Cl}, \mathrm{C}$. albicans cells suspended in alkaline medium $\left(\mathrm{pH}\right.$ 8.0) underwent a high $\mathrm{K}^{+}$release, higher than that induced by lactoferrin alone and in a similar percentage to that previously reported for $S$. cerevisiae cells exposed to $\mathrm{NH}_{4} \mathrm{Cl}$ [38]. Despite the high percentage of $\mathrm{K}^{+}$released (approximately $54 \%$ ), the viability of the $\mathrm{NH}_{4} \mathrm{Cl}$-treated cells remained unchanged, supporting again that the depletion of $\mathrm{K}^{+}$alone was not a sufficient intracellular signal to initiate the RCD process. Moreover, this result suggested that the protective effect of $\mathrm{NH}_{4} \mathrm{Cl}$ observed on hLf-treated cells could be associated with its alkalizing effect on the cytosol rather than with its ability to induce a high $\mathrm{K}^{+}$release. Furthermore, the suggested importance of cytosolic $\mathrm{pH}$ as an initiator of the cell death process was supported by the important loss of cell viability (approximately $53 \%$ of cell survival) caused by the $\mathrm{K}^{+} / \mathrm{H}^{+}$ionophore nigericin that facilitates $\mathrm{K}^{+}$depletion by allowing an $\mathrm{H}^{+}$influx, leading to acidification of cytosol.

Previously, we reported that RCD induced by lactoferrin is blocked by piericidin A, an inhibitor of the respiratory complex I of C. albicans cells [4]. Here, our data indicated that $\mathrm{K}^{+}$-efflux induced by lactoferrin was not modified in cells pre-incubated with piericidin A, suggesting that: (a) The $\mathrm{K}^{+}$-efflux precedes the previously reported mitochondrial events involved in this RCD process; and (b) Pro-apoptotic intracellular events activated by $\mathrm{K}^{+}$-depletion, such as activation of hydrolytic enzymes, vacuolar collapse and hyperpolarization of the plasma membrane, are not involved in this type of RCD $[4,9,12,17,23]$.

All these findings together with our previously reported observations underscore the importance of $\mathrm{K}^{+}$-efflux ab initio of the RCD induced by lactoferrin, but clearly show that this early event is not sufficient to initiate this cell death pathway [2,4,32]. Given all these assertions, we reasoned that cytosolic acidification caused by the rapid blocking effect of lactoferrin on the Pma1p $\mathrm{H}^{+}$-ATPase could be the triggering signal of this type of RCD [4].

Cytosolic acidification is an early apoptotic event observed in cells from multicellular and unicellular eukaryotic organisms exposed to different apoptogenic stimuli [26-28,31]. Therefore, we address the question of whether the decrease of cytosolic $\mathrm{pH}$ could trigger the RCD process induced by lactoferrin. In this regard, the kinetic measurement of intracellular $\mathrm{pH}$ using $\mathrm{pHluorin}$ provided three interesting features of this event: (a) Cytosolic acidification was the first detectable event ( $\leq 1 \mathrm{~min}$ after addition of the lactoferrin) associated to RCD; (b) This rapid drop of intracellular $\mathrm{pH}$ (acidic $\mathrm{pH}$ shift) was estimated in approximately $0.3 \mathrm{pH}$ units at $1 \mathrm{~min}$, a $\mathrm{pH}$ value similar to that previously reported for apoptosis of higher eukaryotic cells [26,28,31]; and (c) Remarkably, the cytosolic acidification induced by lactoferrin was transitory, recovering the initial $\mathrm{pH}$ value after approximately $7 \mathrm{~min}$ of the addition of lactoferrin. These data provided clear evidence of a rapid change in cytosolic $\mathrm{pH}$ as a result of an external stimulus, the specific interaction of lactoferrin with Pma1p $\mathrm{H}^{+}$-ATPase. It should be noted that the kinetics of the assays performed to evaluate $\mathrm{K}^{+}$-efflux and cytosolic acidification showed that the acidic $\mathrm{pH}$ shift preceded the $\mathrm{K}^{+}$-efflux, a finding that is consistent with our previous results arguing against the role of $\mathrm{K}^{+}$-efflux as a trigger for this RCD. Both cytosolic events (i.e., cytosolic acidification and $\mathrm{K}^{+}$-efflux), consequence of the lethal pas-de-deux of Pma1p $\mathrm{H}^{+}$-ATPase and Tok1p channels, were the earliest activation signals of the RCD sequence. Inhibition of only one of these events was sufficient to inhibit lactoferrin-induced cell death, as observed when cells were pre-incubated with $\mathrm{NH}_{4} \mathrm{Cl}$ or $\mathrm{K}^{+}$-channel-blocking agents.

There are previously reported data that apparently support the idea that cytosolic acidification is an inducing signal of cell death in fungi. For example, many of the RCD inductors in fungi are weak acids or acidic compounds, such as acetic acid, acetylsalicylic acid, formic acid, valproic acid, propionic acid, and chlorogenic acid [21,46-51]. These compounds rapidly access the cytosol to be dissociated into protons and their counterions, causing a drop of cytosolic $\mathrm{pH}$ that may be accompanied by 
$\mathrm{K}^{+}$-efflux, as previously reported $[21,41,43]$. In all these cases, it could be assumed that the continuous entry of a weak acid into the cytosol overwhelms the regulatory mechanisms of intracellular $\mathrm{pH}$. If so, the sudden intracellular acidification (acidic $\mathrm{pH}$ shift) could be a sufficient signal to initiate RCD similar to that induced by lactoferrin in our restricted experimental conditions.

In general, our results and the preceding evidence strongly support that transient acidification of the cytosol (acid pH shift $\geq 0.3 \mathrm{pH}$ units) constitutes per se an RCD-inducing signal and the first intracellular step of this ion signaling pathway. Consistently, other ionic events (i.e., $\mathrm{K}^{+}$-efflux) seems to be a consequence of this initial perturbation of cytosolic $\mathrm{pH}$.

Cytosolic acidification was proposed as an intracellular messenger of several cell pathways associated to the metabolism and growth of eukaryotes, including yeast [29-31]. However, the exact role of the cytosolic accumulation of protons in RCD signaling pathways has not been studied [27,31]. In our case, it is tempting to speculate that an ion-mediated pathway is associated to lactoferrin-induced regulated cell death (Figure 5). This ionic signaling pathway is initiated by the interaction of lactoferrin (ligand, first messenger) with Pma1p $\mathrm{H}^{+}$-ATPase (plasma membrane receptor) of yeast to induce a transient cytosolic acidification (second messenger-like signal) that depolarizes the cell membrane. Depolarization of the membrane causes the opening of voltage-operated $\mathrm{K}^{+}$channels (Tok1p), allowing $\mathrm{K}^{+}$-efflux. This ionic event in addition to cytosolic acidification promotes the previously reported mitochondrial response leading to RCD [4]. To the best of our knowledge, this is the first time that a transient cytosolic acidification is proposed as a triggering signal of a cell death signaling pathway.

In a previous report, we suggested that perturbation of the 'cytosolic ionic homeostasis' leads to an alteration of 'mitochondrial ionic homeostasis', and we showed that a functional $\mathrm{H}^{+}$-ATPase (ATP synthase), translocating protons toward mitochondrial matrix, was essential for the progress of the RCD induced by lactoferrin [4]. In our model, the sudden increase of cytosolic protons coupled to the cytosolic $\mathrm{K}^{+}$-efflux seems to represent concatenated signals that converge at the level of the mitochondria, favoring the simultaneous entry of protons into the mitochondrial matrix, mainly through ATP synthase, and the possible loss of mitochondrial potassium. If so, it could be suggested that the protective effect of extracellular $\mathrm{K}^{+}(\geq 30 \mathrm{mM})$ observed on lactoferrin-treated cells might represent a subrogated protective effect at the mitochondrial level. In such a case, the ionic equilibrium of $\mathrm{K}^{+}$reached on both sides of the cytoplasmic membrane prevents the $\mathrm{K}^{+}$-efflux, preserving a critical cytosolic $\mathrm{K}^{+}$concentration (i.e., $\sim 30 \mathrm{mM}$ ). This concentration of $\mathrm{K}^{+}$would be necessary to presumably prevent an equivalent loss of mitochondrial $\mathrm{K}^{+}$that, otherwise, would favor the entrance of protons to the mitochondrial matrix with lethal consequences for the cell [4].

In conclusion, these findings suggest, for the first time, the existence of a signaling pathway from the cytoplasmic membrane to mitochondria where only ions act as early signaling molecules in a RCD pathway. The acidic $\mathrm{pH}$ shift in the cytosol activated this RCD signaling pathway, resulting in intra-mitochondrial ionic disturbance that promoted a further array of phenotypical features previously detected as apoptotic cell markers [2].

Our experimental design represents a high efficiency model for future sequential dissection of cell death pathways in fungi. Due to many of the hallmarks of the RCD process being evolutionarily well conserved events, it would be interesting to determine whether the findings reported here, obtained in an experimental system of limited complexity, may be extrapolated to the RCD processes of higher eukaryotic cells (i.e., apoptosis). If this were the case, our findings might help to design new therapeutic approaches. 


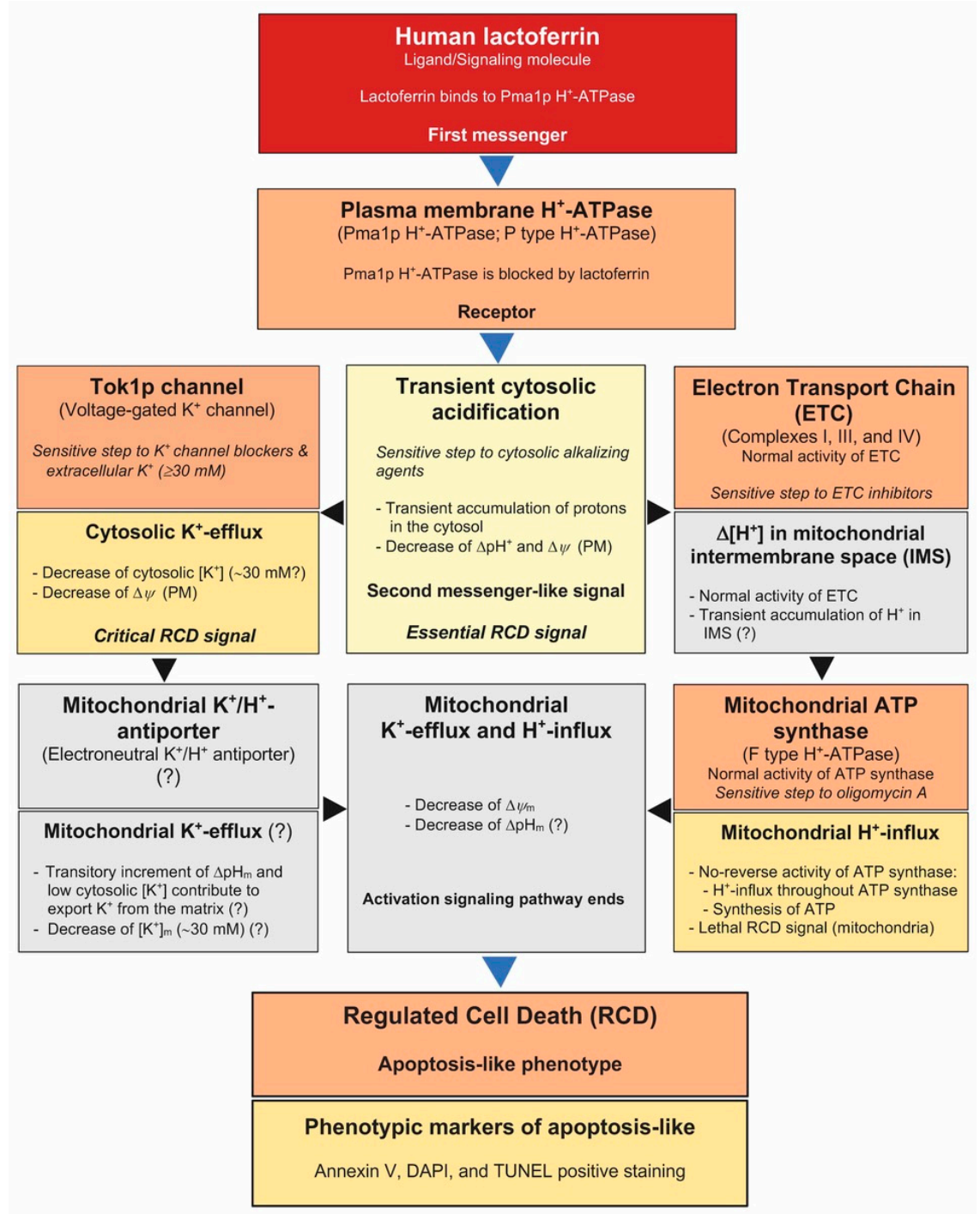

Figure 5. Proposed model of the RCD signaling pathway induced by lactoferrin. The scheme includes hypothetical steps (gray boxes) of this process based on our previously reported data [2,4,32,34]. In yeast cells, Pma1p $\mathrm{H}^{+}$-ATPase actively extrudes $\mathrm{H}^{+}$out the cell and generates a proton gradient $(\Delta \mathrm{pH})$ and an electrical gradient $(\Delta \Psi)$ which allow $\mathrm{pH}$ regulation and the flux of other ions and nutrients across the plasma membrane (PM). The here proposed cell death signaling pathway includes a sequence of ionic events in the cytosol as response to an extracellular signal, as follows: (1) Lactoferrin (hLf, first messenger) binds to the plasma membrane Pma1p $\mathrm{H}^{+}$-ATPase (receptor) blocking this proton pump [4]. (2) Protons are transitorily accumulated in the cytosol, an event detected as a cytosolic acidic $\mathrm{pH}$ shift (second messenger-like signal), inducing a $\Delta \Psi$-decrease. (3) This PM-depolarization opens the voltage-gated $\mathrm{K}^{+}$channel Tok1p, allowing a passive and electrogenic $\mathrm{K}^{+}$-efflux [2,32,34]. (4) Hypothetically, both cytosolic $\mathrm{K}^{+}$depletion and transient cytosolic acidification could favor in turn the loss of mitochondrial potassium, probably via a $\mathrm{K}^{+} / \mathrm{H}^{+}$exchanger, and the simultaneous entry of $\mathrm{H}^{+}$to the mitochondrial matrix, causing a loss of $\Delta \Psi_{\mathrm{m}}$, as reported in [2]. The $\mathrm{H}^{+}$-influx to the matrix, via ATP synthase, is an essential event because inhibition of either electron transfer chain (ETC) or ATP synthase prevented the progress of this cell death pathway [2,4]. (5) The supposed perturbation of the mitochondrial homeostasis could induce further events previously visualized as phenotypic apoptotic markers [2]. Events marked with (?) are hypothetical steps that are being studied. 


\section{Materials and Methods}

\subsection{Materials}

Recombinant human apo-lactoferrin was obtained from Sigma-Aldrich (St. Louis, MO, USA) and Ventria Bioscience (Aurora, CO, USA). Diethylstilbestrol (DES), nigericin, nystatin, piericidin A, tetraethylammonium (TEA), Tris(hydroxymethyl)amino-methane (Tris), and valinomycin were purchased from Sigma-Aldrich. All chemicals used were of analytical grade and were supplied by Sigma-Aldrich. Sabouraud-2\% dextrose broth (SDB) was purchased from Merck KGaA (Darmstadt, Germany).

\subsection{Strains and Growth Conditions}

The Candida albicans strains used in this work are described in Table 1. The strain C. albicans ATCC 10231 was used in this study, unless stated otherwise. The C. albicans DBT2 (TOK1/tok1) and DBT3 (tok1/tok1) strains, obtained by disruption of the TOK1 gene (37), and the parental strain CAI4 (TOK1/TOK1) [52] were generously provided by M. Edgerton (University at Buffalo, Buffalo, NY, USA). These strains were grown in YPD (1\% yeast extract, $2 \%$ peptone, $2 \%$ dextrose) medium. C. albicans JKC1562 and JKC1594, used for the measurement of cytosolic pH, were kind gifts of J.R. Köhler (Harvard University, Boston, MA, USA) and were grown in SDB medium [53,54]. The strains were aerobically cultured in their appropriate medium for $16-20 \mathrm{~h}$ at $30^{\circ} \mathrm{C}$ and subcultured to mid-logarithmic growth phase at $30{ }^{\circ} \mathrm{C}$ in a rotatory shaker (200 r.p.m.), unless stated otherwise. The cells remained in the yeast (blastospore) phase throughout the study. All yeast strains were stored in YPD or SDB with 20\% glycerol at $-80{ }^{\circ} \mathrm{C}$ and sub-cultured in the respective agar ( $2 \%$ ) containing media before each type of test, to ensure optimal growth conditions and purity.

\subsection{Antifungal Assays}

Antifungal activity of lactoferrin was tested in Tris buffer (10 mM Tris- $\mathrm{HCl}, \mathrm{pH} 7.4)$, unless otherwise noted, as previously described [4]. The water used was from a Millipore Milli-Q Plus 185 ultrapure water system. C. albicans cells were cultured in SDB for $16-20 \mathrm{~h}$ at $30{ }^{\circ} \mathrm{C}$ and subcultured to mid-logarithmic growth phase, washed twice in Tris buffer and resuspended in the same buffer. Cell suspensions $\left(10^{5}\right.$ cells $\left./ \mathrm{mL}\right)$ were then incubated in the presence or the absence (control) of lactoferrin for $90 \mathrm{~min}$ at $37^{\circ} \mathrm{C}$, and aliquots were plated on SDA plates (SDB containing $2 \%$ agar). In time-killing kinetic assays, the cells were taken and serially diluted at different intervals after lactoferrin addition and plated on SDA. Unless otherwise specified, cell viability was assessed by colony formation on SDA after $24-48 \mathrm{~h}$ incubation at $30^{\circ} \mathrm{C}$. The survival rates were expressed as a percentage of the number of colonies of samples taken before treatments (defined as 100\%). The viability of nigericin-treated cells under acidic conditions was determined as described, except yeast cells were grown aerobically in SDB to mid-logarithmic growth phase [40]. Every experiment was performed using two technical replicates and repeated independently at least three times.

Table 1. Genotypes and origin of Candida albicans strains used in this study.

\begin{tabular}{|c|c|c|}
\hline Strain & Genotype & Ref. \\
\hline ATCC 10231 & Wild type-clinical strain & ATCC \\
\hline CAI4 & ura3::imm434/ura3::imm434 iro1/iro1::imm434 TOK1/TOK1 & [52] \\
\hline DBT2 & 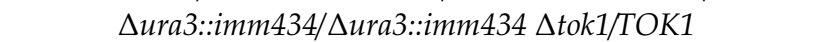 & [37] \\
\hline DBT3 & 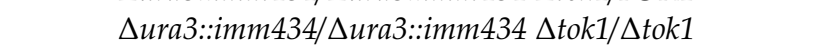 & [37] \\
\hline JKC1562 & 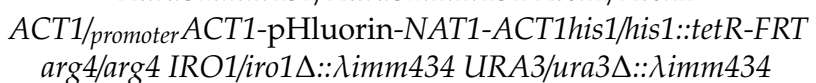 & [53] \\
\hline JKC1594 & 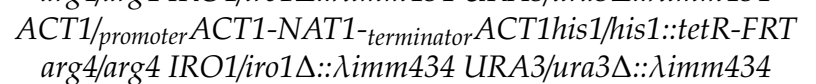 & [54] \\
\hline
\end{tabular}




\subsection{Measurement of Extracellular Potassium}

Potassium measurements were performed by inductively-coupled plasma optical emission spectrometry (ICP-OES) with a Perkin-Elmer Optima 2000 DV spectrometer using yttrium as the internal standard. Cells were cultured in SDB for $16-20 \mathrm{~h}$ at $30^{\circ} \mathrm{C}$, subcultured in SDB to mid-logarithmic growth phase, and rapidly washed in sterile deionized double-distilled water. The cells $\left(10^{7}\right.$ cells $\left./ \mathrm{mL}\right)$ were immediately incubated with different $\mathrm{K}^{+}$depletion inducers at $37^{\circ} \mathrm{C}$. At indicated time-points, tubes were centrifuged at $1100 \times \mathrm{g}$ for $10 \mathrm{~min}$, and supernatants were collected and stored at $4{ }^{\circ} \mathrm{C}$ until analysis. The percentage of cytosolic $\mathrm{K}^{+}$released from cell suspensions treated with $100 \mu \mathrm{g} / \mathrm{mL}$ nystatin was determined in positive control assays. The total $\mathrm{K}^{+}$cellular content $(100 \%$ value) was measured in the supernatant of cellular suspensions previously treated with $0.5 \%(v / v) \mathrm{HClO}_{4}$, heated for $1 \mathrm{~h}$ at $95{ }^{\circ} \mathrm{C}$, and centrifuged to remove cell debris. Results are expressed as the percentage (mean \pm standard deviation) of $\mathrm{K}^{+}$released relative to the total $\mathrm{K}^{+}$content from duplicates of at least three independent assays.

\subsection{Glucose-dependent External Acidification}

Proton pumping activity of Pma1p $\mathrm{H}^{+}$-ATPase was measured by recording the extracellular $\mathrm{pH}$ change after the addition of glucose, as previously described [4,55]. Briefly, C. albicans cells were grown to mid-log phase in SDB medium, harvested by centrifugation and washed twice in Tris buffer. To determine external acidification, the cells were concentrated $\left(10^{7}\right.$ cells $\left./ \mathrm{mL}\right)$ in $30 \mathrm{mM}$ or $50 \mathrm{mM} \mathrm{KCl}$ solutions and pre-incubated without (control) or with $20 \mu \mathrm{M}$ lactoferrin for $15 \mathrm{~min}$ at $37^{\circ} \mathrm{C}$. The $\mathrm{pH}$ of the cell suspensions was adjusted to $\sim 6.7$. Proton extrusion was initiated by the addition of glucose ( $2.5 \mathrm{mM}$, final concentration) and the time-course was followed using a SevenMulti S50-K pH meter (Mettler-Toledo, Greifensee, Switzerland) with constant stirring.

\subsection{Measurement of Cytosolic $\mathrm{pH}$}

The strain C. albicans JKC1562, expressing pHluorin gene from the pJK1027 plasmid, was used to calculate the $\mathrm{pH}$ as described, with slight modifications $[53,56]$. Briefly, the calibration curves were performed using pHluorin-expressing cells, permeabilized with $110 \mu \mathrm{M}$ monensin and $15 \mu \mathrm{M}$ nigericin, resuspended in a series of calibration buffers of defined $\mathrm{pH}(\mathrm{pH} 5$ to 8$)$ to equilibrate their cytosolic $\mathrm{pH}$. The calibration was carried out by adding $20 \mu \mathrm{L}$ of cell suspension $\left(\mathrm{OD}_{600}=0.5\right)$ to $2 \mathrm{~mL}$ of calibration buffer and incubated for $60 \mathrm{~min}$ at $30^{\circ} \mathrm{C}$ before obtaining measurements. For measuring the cytosolic $\mathrm{pH}, 100 \mu \mathrm{L}$ aliquots of cell samples were transferred to a black polystyrene 96-well microtiter plate. The fluorescence of each sample was analyzed with dual excitation wavelengths of $405 \mathrm{~nm}$ and $485 \mathrm{~nm}$ with a $528 \mathrm{~nm}$ emission filter in a Synergy HT Multi-Mode Microplate Reader (BioTek Instruments Inc., Winooski, VT, USA). Fluorescence ratios were recorded, and the cytosolic pH was calculated according to the standard curve. Background fluorescence for a wild-type strain (C. albicans JKC1594) not expressing pHluorin was subtracted from the measurements. The data shown are the means from duplicates of at least three independent experiments.

\subsection{Other Methods}

The ionic strength $(I)$ of each solution was calculated from the concentrations of ions, according to $I=\frac{1}{2} \sum c_{\mathrm{i}} z_{\mathrm{i}}{ }^{2}$, where $c_{\mathrm{i}}$ and $z_{\mathrm{i}}$ are the molar concentration and valence (charge number) of the ionic species (ith) in the solution, respectively.

The osmolar concentration of solutions of different osmolarity was determined in triplicate using an automatic osmometer (mod. OM-6060; Arkray Inc., Kyoto, Japan). The osmometer was calibrated against purified water and commercial standard solutions. 


\subsection{Statistical Methods}

Data were analyzed by using Prism v.6 software (GraphPad Software Inc., San Diego, CA, USA). Student's $t$ test was carried out on data obtained from at least three independent assays performed in duplicate for each sample. Levels of statistical significance at ${ }^{*} p<0.05,{ }^{* *} p<0.01$, and ${ }^{* * *} p<0.001$ were used.

Author Contributions: M.T.A., M.A.-Z., and J.G.-S. performed the laboratory work. M.T.A., M.A.-Z., J.G.-S., and J.F.F. performed the data analysis. J.F.F. and M.T.A. designed and supervised the experiments. J.F.F. wrote the manuscript. All authors contributed to the editing of the manuscript, and approved the final version.

Funding: This work was funded by Servicio para el Control de la Esterilización, Laboratorio de Microbiología Oral (CN-16-036). M.T.A., M.A.-Z. and J.G.-S. were granted by Laboratorio de Microbiología Oral (CN-12-047, $\mathrm{CN}-15-021)$.

Acknowledgments: We thank to Mira Edgerton (University at Buffalo, Buffalo, NY, USA), and Julia R. Köhler (Harvard University, Boston, USA) for kindly providing the modified strains used in this study.

Conflicts of Interest: The authors declare no conflict of interest.

\section{References}

1. Klotz, S.A.; Chasin, B.S.; Powell, B.; Gaur, N.K.; Lipke, P.N. Polymicrobial bloodstream infections involving Candida species: Analysis of patients and review of the literature. Diagn. Microbiol. Infect. Dis. 2007, 59, 401-406. [CrossRef] [PubMed]

2. Andrés, M.T.; Viejo-Diaz, M.; Fierro, J.F. Human lactoferrin induces apoptosis-like cell death in Candida albicans: Critical role of $\mathrm{K}^{+}$-channel-mediated $\mathrm{K}^{+}$efflux. Antimicrob. Agents Chemother. 2008, 52, 4081-4088. [CrossRef] [PubMed]

3. Fernandes, K.E.; Carter, D.A. The antifungal activity of lactoferrin and its derived peptides: Mechanisms of action and synergy with drugs against fungal pathogens. Front. Microbiol. 2017, 8, 2. [CrossRef] [PubMed]

4. Andrés, M.T.; Acosta-Zaldívar, M.; Fierro, J.F. Antifungal mechanism of action of lactoferrin: Identification of $\mathrm{H}^{+}$-ATPase ( $\mathrm{P}_{3 \mathrm{~A}}$-type) as a new apoptotic-cell membrane receptor. Antimicrob. Agents Chemother. 2016, 60, 4206-4216. [CrossRef]

5. Peña, A. Studies on the mechanism of $\mathrm{K}^{+}$transport in yeast. Arch. Biochem. Biophys. 1975, 167, 397-409. [CrossRef]

6. Serrano, R. Structure and function of plasma membrane ATPase. Ann. Rev. Plant. Physiol. Plant Mol. Biol. 1989, 40, 61-94. [CrossRef]

7. Ariño, J.; Ramos, J.; Sychrová, H. Monovalent cation transporters at the plasma membrane in yeasts. Yeast 2019, 36, 177-193. [CrossRef]

8. Acosta-Zaldívar, M.; Andrés, M.T.; Rego, A.; Pereira, C.S.; Fierro, J.F.; Côrte-Real, M. Human lactoferrin triggers a mitochondrial- and caspase-dependent regulated cell death in Saccharomyces cerevisiae. Apoptosis 2016, 21, 163-173. [CrossRef]

9. Bortner, C.D.; Hughes, F.M., Jr.; Cidlowski, J.A. A primary role for $\mathrm{K}^{+}$and $\mathrm{Na}^{+}$efflux in the activation of apoptosis. J. Biol. Chem. 1997, 272, 32436-32442. [CrossRef]

10. Yu, S.P.; Yeh, C.H.; Sensi, S.L.; Gwag, B.J.; Canzoniero, L.M.; Farhangrazi, Z.S.; Ying, H.S.; Tian, M.; Dugan, L.L.; Choi, D.W. Mediation of neuronal apoptosis by enhancement of outward potassium current. Science 1997, 278, 114-117. [CrossRef]

11. Dallaporta, B.; Hirsch, T.; Susin, S.A.; Zamzami, N.; Larochette, N.; Brenner, C.; Marzo, I.; Kroemer, G. Potassium leakage during the apoptotic degradation phase. J. Immunol. 1998, 160, 5605-5615. [PubMed]

12. Hughes, F.M.; Cidlowski, J.A. Potassium is a critical regulator of apoptotic enzymes in vitro and in vivo. Adv. Enzyme Regul. 1999, 39, 157-171. [CrossRef]

13. Park, I.S.; Kim, J.E. Potassium efflux during apoptosis. J. Biochem. Mol. Biol. 2002, 35, 41-46. [CrossRef] [PubMed]

14. Yu, S.P. Regulation and critical role of potassium homeostasis in apoptosis. Prog. Neurobiol. 2003, 70, 363-386. [CrossRef]

15. Burg, E.D.; Remillard, C.V.; Yuan, J.X. $\mathrm{K}^{+}$channels in apoptosis. J. Membr. Biol. 2006, 209, 3-20. [CrossRef] 
16. Peters, J.; Chin, C.-K. Potassium loss is involved in tobacco cell death induced by palmitoleic acid and ceramide. Archiv. Biochem. Biophys. 2007, 465, 180-186. [CrossRef]

17. Hoeberichts, F.A.; Pérez-Valle, J.; Montesinos, C.; Mulet,J.M.; Planes, M.D.; Hueso, G.; Yenush, L.; Sharma, S.C.; Serrano, R. The role of $\mathrm{K}^{+}$and $\mathrm{H}^{+}$transport systems during glucose- and $\mathrm{H}_{2} \mathrm{O}_{2}$-induced cell death in Saccharomyces cerevisiae. Yeast 2010, 27, 713-725. [CrossRef]

18. Klein, B.; Wörndl, K.; Lütz-Meindl, U.; Kerschbaum, H.H. Perturbation of intracellular $\mathrm{K}^{+}$homeostasis with valinomycin promotes cell death by mitochondrial swelling and autophagic processes. Apoptosis 2011, 16, 1101-1117. [CrossRef]

19. Demidchik, V.; Straltsova, D.; Medvedev, S.S.; Pozhvanov, G.A.; Sokolik, A.; Yurin, V. Stress-induced electrolyte leakage: The role of $\mathrm{K}^{+}$-permeable channels and involvement in programmed cell death and metabolic adjustment. J. Exp. Bot. 2014, 65, 1259-1270. [CrossRef]

20. Kunzelmann, K. Ion channels in regulated cell death. Cell Mol. Life Sci. 2016, 73, 2387-2403. [CrossRef]

21. Yun, J.; Lee, D.G. Role of potassium channels in chlorogenic acid-induced apoptotic volume decrease and cell cycle arrest in Candida albicans. Biochim. Biophys. Acta. 2017, 1861, 585-592. [CrossRef] [PubMed]

22. Lee, W.; Lee, D.G. Potential role of potassium and chloride channels in regulation of silymarin-induced apoptosis in Candida albicans. IUBMB Life 2018, 70, 197-206. [CrossRef] [PubMed]

23. Montague, J.W.; Bortner, C.D.; Hughes, F.M., Jr.; Cidlowski, J.A. A necessary role for reduced intracellular potassium during the DNA degradation phase of apoptosis. Steroids 1999, 649, 563-569. [CrossRef]

24. Marklund, L.; Behnam-Motlagh, P.; Henriksson, R.; Grankvist, K. Bumetanide annihilation of amphotericin B-induced apoptosis and cytotoxicity is due to its effect on cellular $\mathrm{K}^{+}$flux. J. Antimicrob. Chemother. 2001, 48, 781-786. [CrossRef]

25. El Kebir, D.; József, L.; Khreiss, T.; Filep, J.G. Inhibition of $\mathrm{K}^{+}$efflux prevents mitochondrial dysfunction, and suppresses caspase-3-, apoptosis-inducing factor-, and endonuclease G-mediated constitutive apoptosis in human neutrophils. Cell Signal. 2006, 18, 2302-2313. [CrossRef]

26. Matsuyama, S.; Reed, J.C. Mitochondria-dependent apoptosis and cellular $\mathrm{pH}$ regulation. Cell Death Differ. 2000, 7, 1155-1165. [CrossRef]

27. Matsuyama, S.; Llopis, J.; Deveraux, Q.L.; Tsien, R.Y.; Reed, J.C. Changes in intramitochondrial and cytosolic pH: Early events that modulate caspase activation during apoptosis. Nat. Cell Biol. 2000, 2, 318-325. [CrossRef]

28. Lagadic-Gossmann, D.; Huc, L.; Lecureur, V. Alterations of intracellular $\mathrm{pH}$ homeostasis in apoptosis: Origins and roles. Cell Death Differ. 2004, 11, 953-961. [CrossRef]

29. Schüller, C.; Brewster, J.L.; Alexander, M.R.; Gustin, M.C.; Ruis, H. The HOG pathway controls osmotic regulation of transcription via the stress response element (STRE) of the Saccharomyces cerevisiae CTT1 gene. EMBO J. 1994, 13, 4382-4389. [CrossRef]

30. Dechant, R.; Binda, M.; Lee, S.S.; Pelet, S.; Winderickx, J.; Peter, M. Cytosolic pH is a second messenger for glucose and regulates the PKA pathway through V-ATPase. EMBO J. 2010, 29, 2515-2526. [CrossRef]

31. Orij, R.; Brul, S.; Smits, G.J. Intracellular pH is a tightly controlled signal in yeast. Biochim. Biophys. Acta 2011, 1810, 933-944. [CrossRef] [PubMed]

32. Viejo-Diaz, M.; Andrés, M.T.; Fierro, J.F. Modulation of in vitro fungicidal activity of human lactoferrin against Candida albicans by extracellular cation concentration and target cell metabolic activity. Antimicrob. Agents Chemother. 2004, 48, 1242-1248. [CrossRef] [PubMed]

33. Yeaman, M.R.; Yount, N.Y. Mechanisms of antimicrobial peptide action and resistance. Pharmacol. Rev. 2003, 55, 27-55. [CrossRef] [PubMed]

34. Viejo-Diaz, M.; Andrés, M.T.; Fierro, J.F. Effects of human lactoferrin on the cytoplasmic membrane of Candida albicans cells related with its candidacidal activity. FEMS Immunol. Med. Microbiol. 2004, 42, 181-185. [CrossRef] [PubMed]

35. Vergani, P.; Miosga, T.; Jarvis, S.M.; Blatt, M.R. Extracellular $\mathrm{K}^{+}$and $\mathrm{Ba}^{2+}$ mediate voltage-dependent inactivation of the outward-rectifying $\mathrm{K}^{+}$channel encoded by the yeast gene TOK1. FEBS Lett. 1997, 405, 337-344. [CrossRef]

36. Bertl, A.; Slayman, C.L.; Gradmann, D. Gating and conductance in an outward-rectifying $\mathrm{K}^{+}$channel from the plasma membrane of Saccharomyces cerevisiae. J. Membr. Biol. 1993, 132, 183-199. [CrossRef] 
37. Baev, D.; Rivetta, A.; Li, X.S.; Vylkova, S.; Bashi, E.; Slayman, C.L.; Edgerton, M. Killing of Candida albicans by human salivary histatin 5 is modulated, but not determined, by the potassium channel TOK1. Infect. Immun. 2003, 71, 3251-3260. [CrossRef]

38. Bañuelos, M.A.; Sychrová, H.; Bleykasten-Grosshans, C.; Souciet, J.L.; Potier, S. The Nhal antiporter of Saccharomyces cerevisiae mediates sodium and potassium efflux. Microbiology 1998, 144, 2749-2758.

39. Marešová, L.; Hušeková, B.; Urbánková, E.; Chaloupka, R.; Sychrová, H. New applications of pHluorin-measuring intracellular $\mathrm{pH}$ of prototrophic yeasts and determining changes in the buffering capacity of strains with affected potassium homeostasis. Yeast 2010, 27, 317-325.

40. Sokolov, S.; Knorre, D.; Smirnova, E.; Markova, O.; Pozniakovsky, A.; Skulachev, V.; Severin, F. Ysp2 mediates death of yeast induced by amiodarone or intracellular acidification. Biochim. Biophys. Acta 2006, 1757, 1366-1370. [CrossRef]

41. Lauff, D.B.; Santa-María, G.E. Potassium deprivation is sufficient to induce a cell death program in Saccharomyces cerevisiae. FEMS Yeast Res. 2010, 10, 497-507. [CrossRef] [PubMed]

42. Hegedús, N.; Leiter, E.; Kovács, B.; Tomori, V.; Kwon, N.-J.; Emri, T.; Marx, F.; Batta, G.; Csernoch, L.; Haas, H.; et al. The small molecular mass antifungal protein of Penicillium chrysogenum-a mechanism of action oriented review. J. Basic Microbiol. 2011, 51, 561-571. [CrossRef] [PubMed]

43. Stratford, M.; Nebe-von-Caron, G.; Steels, H.; Novodvorska, M.; Ueckert, J.; Archer, D.B. Weak-acid preservatives: $\mathrm{pH}$ and proton movements in the yeast Saccharomyces cerevisiae. Int. J. Food Microbiol. 2013, 161, 164-174. [CrossRef] [PubMed]

44. Yenush, L. Potassium and sodium transport in yeast. Adv. Exp. Med. Biol. 2016, 892, 187-228. [PubMed]

45. Bertl, A.; Bihler, H.; Reid, J.D.; Kettner, C.; Slayman, C.L. Physiological characterization of the yeast plasma membrane outward rectifying $\mathrm{K}^{+}$channel, DUK1 (TOK1), in situ. J. Membr. Biol. 1998, 162, 67-80. [CrossRef]

46. Sousa, M.J.; Ludovico, P.; Rodrigues, F.; Leão, C.; Côrte-Real, M. Stress and cell death in yeast induced by acetic acid. In Cell Metabolism-Cell Homeostasis and Stress Response; Bubulya, P., Ed.; IntechOpen: Rijeka, Croatia, 2012. [CrossRef]

47. Lastauskienè, E.; Zinkevičienè, A.; Girkontaitè, I.; Kaunietis, A.; Kvedarienè, V. Formic acid and acetic acid induce a programmed cell death in pathogenic Candida species. Curr. Microbiol. 2014, 69, 303-310. [CrossRef]

48. Balzan, R.; Sapienza, K.; Galea, D.R.; Vassallo, N.; Frey, H.; Banister, W.H. Aspirin commits yeast cells to apoptosis depending on carbon source. Microbiology 2004, 150, 109-115. [CrossRef]

49. Du, L.; Su, Y.; Sun, D.; Zhu, W.; Wang, J.; Zhuang, X.; Zhou, S.; Lu, Y. Formic acid induces Yca1p-independent apoptosis-like cell death in the yeast Saccharomyces cerevisiae. FEMS Yeast Res. 2008, 8, 531-539. [CrossRef]

50. Mutoh, N.; Kitajima, S.; Ichihara, S. Apoptotic cell death in the fission yeast Schizosaccharomyces pombe induced by valproic acid and its extreme susceptibility to $\mathrm{pH}$ change. Biosci. Biotechnol. Biochem. 2011, 75, 1113-1118. [CrossRef]

51. Yun, J.; Lee, D.G. A novel fungal killing mechanism of propionic acid. FEMS Yeast Res. 2016, 16. [CrossRef]

52. Fonzi, W.A.; Irwin, M.Y. Isogenic strain construction and gene mapping in Candida albicans. Genetics 1993, 134, 717-728. [PubMed]

53. Liu, N.-N.; Köhler, J.R. Antagonism of fluconazol and a proton pump inhibitor against Candida albicans. Antimicrob. Agents Chemother. 2016, 60, 1145-1147. [CrossRef] [PubMed]

54. Liu, N.-N.; Flanagan, P.R.; Zeng, J.; Niketa, M.J.; Cardenas, M.E.; Moran, G.P.; Köhler, J.R. Phosphate is the third nutrient monitored by TOR in Candida albicans and provides a target for fungal-specific indirect TOR inhibition. Proc. Natl. Acad. Sci. USA 2017, 114, 6346-6351. [CrossRef] [PubMed]

55. Serrano, R. Effect of ATPase inhibitors on the proton pump of respiratory-deficient yeast. Eur. J. Biochem. 1980, 105, 419-424. [CrossRef]

56. Diakov, T.T.; Tarsio, M.; Kane, P.M. Measurement of vacuolar and cytosolic $\mathrm{pH}$ in vivo in yeast cell suspensions. J. Vis. Exp. 2013, 74, e50261. [CrossRef]

(C) 2019 by the authors. Licensee MDPI, Basel, Switzerland. This article is an open access article distributed under the terms and conditions of the Creative Commons Attribution (CC BY) license (http://creativecommons.org/licenses/by/4.0/). 